\title{
AGRARIAN LAND POLICY ON LAND IN INDONESIA POST REGIONAL AUTONOMY
}

\author{
Bintang Ulya Kharisma ${ }^{1}$ \\ Universitas PGRI Madiun \\ Corresponding Authors Email1: bintangkharisma25@gmail.com \\ Pryo Sularso ${ }^{2}$ \\ Universitas PGRI Madiun \\ Email2: pryosularso@unipma.ac.id \\ Bintara Sura Priambada ${ }^{3}$ \\ Universitas Surakarta \\ Email³: bintara.sp@gmail.com \\ Asri Agustiwi ${ }^{4}$ \\ Universitas Surakarta \\ Email4: tiwiasri26@gmail.com \\ Siti Wulandari ${ }^{5}$ \\ Universitas PGRI Madiun \\ Email5: wulandaysiti@gmail.com \\ DOI: https://doi.org/10.31764/jmk.v11i2.3258
}

Received: Augt 30, 2020, Accepted: Sept 30, 2020 /Published: Okt 31, 2020

\begin{abstract}
This study aims to discuss the agrarian law policy in the land sector in Indonesia after regional autonomy. The method used in this research is a normative juridical approach by examining and interpreting theoretical matters regarding the principles, conceptions, doctrines, and legal norms related to land law after post regional autonomy. The research specifications in this research are descriptive analytic using secondary data, including primary legal materials consisting of statutory regulations, official records or minutes of the formation of laws and regulations relating to the issues discussed, and secondary legal materials including books, legal journals., and papers. This study result is that agrarian land policies began in the reform era during the reign of President BJ Habibie, who issued Presidential Decree No. 48/1999 concerning the Policy and Regulatory Study Team in the context Landreform implementation. This policy applies simultaneously with the initiation of regional autonomy. The existence of agrarian reform, especially in the land sector, aims to be advanced, just and independent. The transformation of agrarian reform lies in the arrangement of agrarian resources in an effort to eliminate gaps in land tenure rights and change the pattern of agricultural life to be more productive and sustainable.
\end{abstract}

Keywords: agrarian law; land; post regional autonomy. 
Penelitian ini bertujuan untuk membahas kebijakan hukum agraria di sektor pertanahan di Indonesia setelah otonomi daerah. Metode yang digunakan dalam penelitian ini adalah pendekatan yuridis normatif dengan memeriksa dan menafsirkan hal-hal teoritis mengenai prinsip, konsepsi, doktrin, dan norma hukum terkait hukum pertanahan setelah pasca otonomi daerah. Spesifikasi penelitian dalam penelitian ini adalah analitik deskriptif menggunakan data sekunder, termasuk materi hukum primer yang terdiri dari peraturan perundang-undangan, catatan resmi atau risalah pembentukan peraturan perundang-undangan yang berkaitan dengan masalah yang dibahas, dan materi hukum sekunder termasuk buku, jurnal hukum, dan makalah. Hasil kajian ini adalah kebijakan lahan agraria dimulai pada era reforma pada masa pemerintahan Presiden BJ Habibie, yang menerbitkan Keputusan Presiden Nomor 48 Tahun 1999 tentang Tim Kajian Kebijakan dan Regulasi dalam rangka implementasi Landreform. Kebijakan ini berlaku bersamaan dengan inisiasi otonomi daerah. Adanya reforma agraria, khususnya di sektor pertanahan, bertujuan untuk maju, berkilasi dan mandiri. Transformasi reforma agraria terletak pada penataan sumber daya agraria dalam upaya menghilangkan kesenjangan hak penguasaan lahan dan mengubah pola kehidupan pertanian menjadi lebih produktif dan berkelanjutan.

Kata kunci: hukum agraria; daratan; pasca otonomi daerah.

\section{INTRODUCTION}

Indonesia is known in the world to have strong indigenous/indigenous peoples. The problem of globalization of land law is to reaffirm local wisdom. In other words, they are upholding the customary provisions related to land. Example: provisions of customary land. ${ }^{1}$ In land ownership, community land rights are also known. In Indonesia it is called ulayat land. Normatively, customary law community land rights are highly recognized as regulated in Article 3 of Law Number 5 of 1960 concerning Basic Agrarian Regulations with the provision that by taking into account the provisions of Articles 1 and $2^{2}$ Regarding the implementation of customary rights and similar rights to customary law communities, as long as the reality is still there, it must be so, so that it is

1 Rina Rohayu. Harun, 2019. "Menyikapi Globalisasi Hukum Tanah dengan Kearifan Lokal". Media Keadilan: Jurnal Ilmu Hukum. https:// doi.org/10.31764/jmk.v10i2.2250. Hal 219.

2 Pasal 3 Undang-Undang Nomor 5 Tahun 1960 tentang Peraturan Dasar Pokok-Pokok Agraria

Volume 11 Nomor 2, Oktober 2020 (129-155) | Media Keadilan: Jurnal Ilmu Hukum | 
in line with national and state interests which are based on national unity and must not conflict with laws and regulations and other higher regulations.

This is a breath of fresh air after 30 years of President Suharto's term, the Indonesian system of government has become increasingly centralized and autocratic. Indeed, these two features of governance are mutually reinforcing and tend to ignore the needs of regions and communities. Since President Suharto stepped down in May 1998, Indonesia has experienced a dramatic push towards democracy. Marked by free elections, press freedom, and calls for reform nationally, this democratization process also raises regional demands on the central government to decentralize its powers and functions. While decentralization also has the potential for unrest in the short term, demands from the regions for greater autonomy are now too strong to ignore. ${ }^{3}$

In the long term, decentralization has the potential to stabilize political, economic and social conditions in Indonesia. What is needed, however, is a realistic timetable for decentralization that balances demands for regional autonomy with the capacity of local governments to carry out their new functions. The new policy of decentralization and regional autonomy is outlined in Law no. 22 of 1999 concerning Regional Government and Law no. 25 of 1999 concerning Financial Balance between Central and Regional Government ${ }^{4}$. Both laws are based on five principles: 1) democracy, 2) community participation and empowerment, 3) equity

\footnotetext{
3 The SMERU Research Institute, Regional Autonomy in Indonesia, A Paper Prepared for $7^{\text {th }}$ PRSCO Summer Intitute, Bali, 20-21 Juni 2020.

4 UU No. 22 Tahun 1999 tentang Pemerintah Daerah dan UU No. 25 Tahun 1999 tentang Perimbangan Keuangan Antara Pemerintah Pusat dan Daerah.
} 
and justice, 4) recognition of potential and diversity in the regions, and 5) the need to strengthen regional legislatures. ${ }^{5}$

These five principles support Indonesia's push for reform, which continues to strive to eradicate corruption, collusion and nepotism (KKN), within the government bureaucracy. One of the specific reasons behind the policies of decentralization and regional autonomy is that it is impossible for a centralized government system to regulate Indonesia's population of more than 203 million$^{6}$ with diverse socio-cultural and religious backgrounds. Strong, competent local government and greater autonomy are fundamental requirements for a country as diverse as Indonesia. The main objective of decentralization and regional autonomy is to bring the government closer to its constituents so that government services can be delivered more effectively and efficiently. This is based on the assumption that district and city governments understand the needs and aspirations of their citizens better than the central government. Although there is considerable potential for district and city governments to be more responsive to the aspirations of the community, previously political parties and civil society groups in the regions need to be strengthened so that the process of good governance can run well.

Politically, it can be said that the essence of regional autonomy is to restore the "dignity" of the regions which have been controlled by the central government ${ }^{7}$. From this perspective, it appears that regional autonomy which is formulated based on the pluralism paradigm can be said to be part of efforts to save the country. The autonomy granted to the regions will promote and strengthen national integration ${ }^{8}$. Such a

5 UU No. 22 Tahun 1999 tentang Pemerintah Daerah dan UU No. 25 Tahun 1999 tentang Perimbangan Keuangan Antara Pemerintah Pusat dan Daerah.

${ }^{6}$ BPS, 2002, Statistik Indonesia, Jakarta, www.bps.go, Diakses pada 4 Oktober 2020.

7 The SMERU Research Institute, Regional Autonomy in Indonesia, A Paper Prepared for $7^{\text {th }}$ PRSCO Summer Intitute, Bali, 20-21 Juni 2020.

8 ibid 
paradigm cannot be inferred from only one theory of national integration, but needs to be strengthened from the empirical evidence of countries that have experienced decentralization as a result of excessive control under centralized government, as well as the experience of several countries remaining integrated under autonomous or federated systems. Despite strong support for regional autonomy, it is not surprising that many still perceive the new system as a threat.

One of the things that entered into changes during the reform era or during the implementation of regional autonomy was the standard model for agrarian reform, namely simple land redistribution or land reform. The land object was divided into many plots and given to landless farmers. Land reform has been carried out during the 1960s to $1990 \mathrm{~s}^{9}$. In the early period, the objects of land redistribution were mostly non-existing agricultural land and land that was excessively above the maximum ownership limit.

\section{METHODOLOGY}

The method used in this study is a normative juridical approach by examining and interpreting theoretical matters regarding the principles, conceptions, doctrines, and legal norms related to land law after postregional autonomy. The research specifications in this study are descriptive analytics using secondary data, including primary legal material consisting of legislation, official records or treatises on the formation of legislation relating to the issues discussed, and secondary legal materials including books, legal journals, and papers.

9 M. Sadyohutomo, 2018, The Benefits of an Agrarian Reform Model in Indonesia, IOP Conferentioon Earth and Environtmental Science 202. 


\section{DISCUSSION}

\section{A. History of Agrarian Law in Indonesia}

The constitutional reforms following the fall of President General Suharto's autocratic regime in 1998 gave broad powers to local governments having resulted in Indonesia operating in practice as a "quasi-federation". Regardless of the official name, the asymmetrical system of authority between Indonesian provinces creates variations in the levels of authority and the share of natural resource revenues they receive $^{10}$. Most provinces operate under the post-Suharto regional autonomy system, while special autonomy only applies to the provinces of Aceh, Papua and West Papua. Both regional and specialized authorities have significant pledges to improve the accountability, efficiency, sustainability and equity of resource management, but both have largely failed to fulfill that promise due to failure to implement adequate safeguards and develop local capacities to fulfill their responsibilities.

Regional autonomy laws do not centralize control over policymaking and operations in public works, health, education and culture, agriculture, industry and trade, investment, environment, land administration, and co-operative and labor affairs, and thus relocate about two-thirds of the total Indonesian civil servants for local government. Indonesia's regional autonomy legislation is often cited as an explosion of radically rearranging powers and responsibilities. Therefore, the new political class is under strong popular pressure to immediately reform the highly centralized and predatory state bureaucracy which in the eyes of many people has become synonymous

10 Anonim, Quasi Federalism in Indonesia, Draft Forenst Trend, https://www.forest-trends.org/wpcontent/uploads/imported/6-quasi-federalism-in-indonesia-pdf.pdf, Diakses pada 5 Oktober 2020 
with kleptocracy, injustice and impunity, and failure to meet and even indifference to the development of citizens' needs his country. ${ }^{11}$

Decentralization is seen as a way to address problems of injustice and injustice, and to make government more accountable and participatory. Externally, the Asian financial crisis and international donors also played an important role. Under the fiscal decentralization law, the central government receives $84.5 \%$ of net oil revenue from a region, $69.5 \%$ of net gas revenues, and only $20 \%$ of forestry, fisheries, mining and geothermal revenues. In addition, local governments will receive $45 \%$ of the lucrative reforestation fees collected from forestry concessionaires, funds previously controlled unilaterally by the central government. ${ }^{12}$

Decentralization can make resource management more appropriate to local conditions, responsive to local communities and market needs, changing environments, and respecting local rights. However, without the 2 safeguards and preparations mentioned above, the promise of decentralization is limited to a few regions with exemplary local leadership. ${ }^{13}$ Although decentralization relocated broad powers to local governments, in particular, authority over the allocation of oil, gas, mining and forestry concessions and policymaking was largely retained (or revoked in a later revision of laws) by central ministries. This is, in part, due to the lack of clarity in decentralization laws, and contradictory (and strictly, unconstitutional) sectoral laws that attempt to recentralize power over lucrative resources. Although some regional powers have been decentralized under amended laws and regulations, local officials often do not

\footnotetext{
11 ibid

12 C. Barr, Resosudarmo, LA., Mc Carthy J dan Dermawan, 2006, A. Forest and Decentralization in Indonesia, CIFOR, Bogor, $13 \mathrm{ibid}$
} 
recognize their reduced powers and the central government appears unable or unwilling to enforce new laws and regulations, including those relating to agrarian land. ${ }^{14}$

The People's Consultative Assembly (MPR) has issued Decree/Instruction No. IX/2001 concerning Agrarian Reform and Natural Resource Management. The decree mandates the DPR or the Indonesian People's Representative Council (DPR-RI) to draft a bill on the issue in the shortest possible time. The sub-commission in Committee II of the DPR is collecting further information before compiling a draft (RUU) whose title is still being discussed in various groups (NGOs, Farmers, Experts) who have interests but differ on this matter. The National Land Agency (BPN) is also working on an academic paper to provide a solid basis for the bill.

The position of one group is to assist the Basic Agrarian Law (UUPA) no. 5/196015 become comprehensive Laws for technical/sectoral Ministries/Departments to be referred to in their respective Laws (Forestry, Mining, Irrigation, Environment, Transmigration, etc.). The position of another group is to make the agrarian reform law separate from natural resource management, but both refer to Article 33 of the State Constitution and MPR Decree No. IX/2001. ${ }^{16}$ In this somewhat controversial situation, it is questionable to what extent the National Land Agency is mandated to function as an effective coordinating body, directly under the President as Head of the National Cabinet. To answer this question as well as to understand the effect of land policy on society, this paper presents a chronology of

14 S. Ekawati, Kinerja Pemerintah Kabupaten dalam Desentralisasi Pengelolaan Hutan Lindung: Studi Kasus di 3 Kabupaten dalam DAS Batanghari, Jurnal Analisis Kebijakan Kehutanan, Vol. 8 No. 2, Hal. 152-166.

15 UU Pokok Agraria (UUPA) No. 5/1960

16 UUD Negara pasal 33 dan Ketetapan MPR no IX/2001 
changes in Indonesia's agrarian policy starting from the early 19th century to the end of the 20th century.

The emergence of Indonesia from a colony to become a sovereign unitary state has changed the agrarian structure. As an agrarian society with about 60 percent of the population working in or living from agriculture, the government is bound to manage natural resources such as land, water and the wealth they contain as best as possible to realize the welfare of the community. However, the presidents who ruled the country for the past 50 years have mixed opinions about its use, exploitation and management. Therefore, various agrarian policies will be described, including their implications and impacts on agricultural and rural development.

Land fragmentation, poverty and land hunger will be exposed among others. Institutions at the national, regional and local levels will also be discussed as they play an important role in policy implementation. How well people in large rural areas respond to policies depends on local needs. In its quest for staple food selfsufficiency since the 1960s, Indonesia has enthusiastically supported the Green Revolution, which has unwittingly led to an accumulation of land in the hands of the rich. As a result, rural unemployment has increased along with rice production. Moreover, the implementation of land reform and tenancy reform is practically neglected in programs such as developing an integrated legal framework, compiling a national land use map, administering land administration and certification, etc. Beliefs about the need for and a national justification for the implementation of reform must come from the Indonesian government and political elites. Every step forward in this direction is likely to make a positive contribution to overcoming the current multi-crisis situation. A key finding since the mid-1997 crisis, the country's legal system has 
been loosened up and subordination of laws and regulations has been severely weakened.

Reports of conflicts in the regions caused by contradictions between the legality of customary law and state law are increasing day by day. This creates an unstable climate for medium and long term investment by domestic and foreign companies. Instability and uncertainty have also made investors seriously consider relocating their companies to neighboring countries, exacerbating domestic unemployment.

Despite the Regional Autonomy Law no. 22/199917 has been promulgated promising the Bupatis greater competence in land use and allocation, subsequent Presidential Decree No. 10/2001 (made April 2001) appears to have set this promise aside, until it was debated again in May 2003.

The idea of private property is unheard of among some ethnic groups who practice communal agriculture. Since the Dutch era 1 Presidential Decree No. 34/200318 issued on 31 May 2003 clearly regulates the division of land affairs between central and regional governments. There are nine functions given to the regions, including: issuing location permits, providing land for public purposes, settling land disputes, settling land compensation allocated for development, redistribution of land, determining and settling communal land issues, and others. The certification and registration functions remain at the central government level colonialism, land that is considered customary is forcibly taken and marked as state land. This problem was not resolved during Suharto's rule in large part for fear of military retaliation. But the democratic climate of Reformasi that developed in

17 Undang-Undang Otonomi Daerah No. 22/1999

18 Keputusan Presiden No. 34/2003 tanggal 31 Mei 2003 
1998 has prompted some indigenous clans to make claims, some dating from 105 years ago, on state land as their own. Due to pressure from the farmer population in certain districts, the board has taken an independent and firm stance by forming joint committees at the local level whose members represent farmer organizations, DPRD members, administrators and LSM.

Several officials who initiated the formation of these joint local committees then presented their respective cases at a seminar held by the Ministry of Home Affairs, namely the Directorate General of General Administration in June 2002. The cases submitted were named "best practice", highlighting the urgency for finding solutions to agrarian problems, even before the implementation of Agrarian Reform \& Natural Resources Management if it refers to the Assembly Decree (MPR) No. IX of 2001.

The steps taken so far towards Indonesia's macroeconomic recovery do not include the postulate that agrarian reform and effective natural resource management in developing countries are essential for economic recovery. Nor did the reforms include the assumption that poverty reduction in rural areas would be accelerated through land redistribution, and that it would also increase popular support for democratic governance. The drafting of the Agrarian Reform \& Natural Resources Management Bill has not been a priority for the current government for the first half of 2003; was not found among 53 other bills that the DPR had to pass. Considering that Indonesia's founding fathers wished to revive equality, justice and eradication of poverty after a long period of colonialism, this spirit should be reflected in the upcoming Agrarian Reform Law, based on the promulgation of the MPR. Decree No. IX/2001, November 2001. The Basic Agrarian Law (No. 5/1960) promulgated on 24 September 1960 was inspired by the 
spirit of customary law, in which there is communal domination over absolute private ownership (property). ${ }^{19}$ Consequently, the nascent nation-state, established as a modern institution, has control rather than ownership of all agrarian resources (UUPA Chapter I.2), including land, water, air, and all natural resources that are contained under or cover they. The notion of agrarian is defined as all natural resources related to humans/human society, so that naturally it contains the meaning of management and exploitation. ${ }^{20}$

The spirit, interpretation and meaning above are highly recommended to be instilled in the upcoming Agrarian Reform Law, as well as to remind the "sectoralism" in all related laws that have been promulgated previously.

It is highly recommended that the passage of the Agrarian Reform Law referred to above be passed by Parliament in the shortest possible time to prevent anarchist activities and conflicts from becoming wider. ${ }^{21}$ The drafting of a bill can be assigned to a relatively small but independent national committee, which sits outside of parliament and consists of dedicated experts and other indestructible members. ${ }^{22}$

The increase in agrarian conflicts, land grabbing/reclamation, illegal logging and other violations have demanded the establishment of special regional courts, to prevent more widespread violence. This may not be limited to rural areas. As the number of poor landless people continues to increase, and a diseased manufacturing sector is unable to absorb a labor surplus of 2.5 million annually, pulling back from agricultural development as a driver to revive economic growth

19 Undang-Undang Pokok Agraria (No. 5/1960) yang diundangkan pada 24 September 1960

${ }^{20}$ Wiradi dan Tjondronegoro, 2002, Menelusuri Pengertian Istilah Agraria,

21 M. Sadyohutomo, 2018, The Benefits of an Agrarian Reform Model in Indonesia, IOP Conferentioon Earth and Environtmental Science 202.

22 Sediono M.P Tjondronegoro, 2003, Land Policies in Indonesia, EASRD Working Paper, Edisi 19 Juni 2003, 
seems inevitable. Empowerment of the farmer population must include the formation of a free farmer organization, which is ideally represented in the DPR, DPD, DPR and MPR (national). In order to solve the problem of the sectoral approach in the Agrarian Reform Law, it is necessary to immediately enact the "Overarching Agrarian Law". Or the Presidential Instruction should be effective to redirect Sectoral Actions (introduced by the Technical Department). Some argue that it is impossible to find political will to carry out agrarian reform now when Indonesia is still experiencing an economic crisis. Even at the end of the 1970s when Indonesia experienced political stability and a high growth rate of 7 percent of PDB, the government did not take advantage of the moment to carry out land reform in its development plans but maintained the Basic Agrarian Law (BAL) 5/1960 as a reference.

Another alternative solution is to popularize "best practice" experiences by allowing district heads to formalize land use through regional consensus (leveraged land reform). However, what needs to be considered is that this can lead to conflicts between regions if there is no National Land Use Map available. A quick solution is needed to solve the controversial problem between chapters III. ${ }^{23}$

The regional and district governments were confused and critical of the issuance of the above Presidential Regulation because it did not contain legal authority to override an article in a law. This understanding has been revitalized after the 1998 Reformation. The National Land Agency (BPN) which is supposed to be the coordinator in agrarian management must be strengthened again if the sectoral approach is to be overcome. Currently BPN does not have the authority to coordinate, and is only the administrative body for land

${ }^{23}$ UU Otonomi Daerah No. 25/1999, dan Keputusan Presiden No. 10/2001 tentang kompetensi tentang alokasi lahan. 
registration. ${ }^{24}$ The central government needs a strong institution to plan and implement comprehensive Agrarian Reform and through it achieve the efficient management of natural resources that the country so desperately needs.

\section{B. Post-Regional Autonomy Agrarian Law in Indonesia}

Agrarian policy began in the reform era during the reign of President BJ Habibie, who issued Presidential Decree No. 48/1999 concerning the Policy and Regulatory Study Team in the context of Landreform Implementation. This policy applies simultaneously with the initiation of regional autonomy. Another policy was issued in Law Number 41 concerning Forestry on September 30, 1999, which in its application is often a source of agrarian conflict, because it causes agrarian fighters to be thrown in prison. Furthermore, during the Gus Dur era, on October 20,1999 a controversial statement was issued, that $40 \%$ of plantation land originating from community land was confiscated by plantations. Plantation land, especially state owned, originated from the Dutch colonial era with the Domein Verklaring system. ${ }^{25}$

In the era of Megawati Soekarno Putri, agrarian policies were increasingly emphasized by the issuance of TAP MPR Number IX of 2001 concerning Agrarian Reform and Natural Resource Management which encouraged the implementation of agrarian reform. ${ }^{26}$

The content of the MPR Decree is to order the President and the DPR to revoke laws and regulations that are contrary to the

\footnotetext{
24 Ria Fitri, 2018, Hukum Agraria Bidang Pertanahan Setelah Otonomi Daerah, https://jurnal.hukumonline.com/a/5cb490e901fb73000e1c6bee/hukum-agraria-bidangpertanahan-setelah-otonomi-daerah, diakses pada 5 Oktober 2020.

25 Triana Rejekiningsih, 2019, Chatarina Muryani, Diana Lukitasari, Study of the History and Dynamics of the Agrarian Policy in Transforming the Indonesia Agrarian Reform, Yustisia, Vol. 8 No. 2, Edisi Mei-Agustus 2019.

26 TAP MPR Nomor IX Tahun 2001 tentang Pembaruan Agraria dan Pengelolaan Sumber Daya Alam
} 
implementation of agrarian reform. All forms of agrarian reform implementation agenda, the President is obliged to report to the MPR Annual Session. Furthermore, in the era of Susilo Bambang Yudoyono, various agrarian movements grew, including the Federation of Indonesian Peasants' Union (FSPI). The Federation of Indonesian Peasants 'Union which later changed its name to the Agrarian Reform Movement Alliance to the Indonesian Peasants' Alliance (API). The Indonesian Peasants 'Alliance, the Agrarian Reform Movement Alliance (AGRA), the Indonesian Peasants' Union, the Peasants Union at the national level are implementing agrarian reform. ${ }^{27}$ However, on August 11, 2004, Law Number 18 Year 2004 regarding Plantation ${ }^{28}$ was passed which became the entrance for investors to open large-scale plantations (Article 21 and Article 47 paragraph 1 and paragraph 2 dated 19 September 2011 were canceled by the Constitutional Court). Furthermore, Law Number 25 of 2007 concerning Investment was passed which tended to provide a form of liberalization in Indonesia. ${ }^{29}$ As an effort to resolve the conflict that occurred, in other words as a step forward, on June 30, 2004, Komnas HAM established the National Commission for Agrarian Conflict Resolution (KNuPKA) Formation Text. This paper is the result of advocacy and recommendations from the Consortium for Agrarian Reform (KPA) together with civil society organizations and other agrarian experts. ${ }^{30}$ On October 14, 2009, Law Number 41 of 2009 concerning the Protection of Sustainable Food

27 Triana Rejekiningsih, 2019, Chatarina Muryani, Diana Lukitasari, Study of the History and Dynamics of the Agrarian Policy in Transforming the Indonesia Agrarian Reform, Yustisia, Vol. 8 No. 2, Edisi Mei-Agustus 2019.

28 Undang-Undang Nomor 18 Tahun 2004 tentang Perkebunan

29 D. Primayanti dan Ferdyansyah, 2019, Konflik Agraria Antara Gerakan Reforma Agraria Pengalengan dengan Perusahaan Daerag Agribisnisdan Pertambangan, Jurnal Kolaborasi Resolusi Konflik, Vol. I No. 1,

30 Triana Rejekiningsih, 2019, Chatarina Muryani, Diana Lukitasari, Study of the History and Dynamics of the Agrarian Policy in Transforming the Indonesia Agrarian Reform, Yustisia, Vol. 8 No. 2, Edisi Mei-Agustus 2019. 
Agricultural Land was passed, which restricts the rate of conversion of agricultural land to non-agricultural land. On January 22, 2010 Government Regulation of the Republic of Indonesia Number 11 of 2010 concerning Control and Utilization of Abandoned Land, this regulation is intended to curb and increase the economic value of the abandoned land. ${ }^{31}$ Furthermore, Larasita policy was passed; which in fact leads to land liberalization in Indonesia. In fact, this policy is claimed to be a breakthrough for the mobile office to certify community land to villages. However, what happens is that if land certification practices inequality, the agrarian structure (ownership, control and use of land) will in fact legalize the unbalanced structure. The certification process through Larasita, which was not preceded by agrarian reform, tended to create a liberal land market which was very contradictory to the 1960 Basic Agrarian Law. Because there were imbalances in land ownership and control by the people, meanwhile only a few people and business entities who control large areas of land. Then the bias is certification legalizing inequality. ${ }^{32}$

Partisanship of agrarian affairs began to appear in the era of President Joko Widodo (Jokowi) leadership, on 26 October 2014 the Ministry of Agriculture and Spatial Planning was formed, the purpose of establishing this ministry is to resolve possible agrarian conflicts. Furthermore, on April 13, 2016, the Ministry of Agrarian Affairs and Spatial Planning/National Land Agency handed over 383 hectares of land and 1,250 certificates to farmers from Badega, Garut, West Java, who had been fighting over 498 hectares of land since the Japanese era.

\footnotetext{
31 Peraturan Pemerintah Republik Indonesia Nomor 11 Tahun 2010 tentang Penguasaan dan Pemanfaatan Tanah

32 D. Primayanti dan Ferdyansyah, 2019, Konflik Agraria Antara Gerakan Reforma Agraria Pengalengan dengan Perusahaan Daerag Agribisnisdan Pertambangan, Jurnal Kolaborasi Resolusi Konflik, Vol. I No. 1,
} 
On December 30, 2016, President Jokowi submitted a Decree on the Recognition of Customary Forests to nine (9) indigenous peoples and divided the land area of 12,000 ha. The Jokowi era is planned to distribute 12.7 million hectares of forest to the community, both farmers and indigenous people. The government also plans to distribute land certificates to the community covering an area of 4.5 million hectares. Certification is part of land legalization. The government is targeting 9 million ha of land to be certified by 2019. The 0.6 million hectare land is uncertified transmigration land. The remaining 3.9 million hectares are the result of legalization of community land assets. Meanwhile, for land redistribution, namely 0.4 million ha of HGU and abandoned land, and 4.1 million ha of land resulting from the release of forest areas. Furthermore, the Ministry of Environment and Forestry issued Ministerial Regulation Number P.83/MENLHK/SETJEN/KUM.1/10/2016 concerning Social Forestry which regulates community access related to forest and agrarian resources in it by providing community access to utilize a plot of land in forest area within a certain period of time, namely for 35 years with an evaluation carried out every five years. The government is targeting 12.7 million ha of forest land to be the object of social forestry. The Indicative Map of Perhutani Sosial Area (PIAPS) has been prepared by the Ministry of Environment and Forestry and is spread across almost all provinces, including in Perhutani's working areas. However, specifically for Perhutani Sosial in the Perhutani area, there is a Ministerial Regulation which specifically regulates the Ministerial Regulation Number P.39/MENLHK/SETJEN/KUM.1/6/2017 concerning Perhutani Sosial in Perhutani Housing Areas ${ }^{33}$. This

33 Peraturan Menteri Nomor P.39/MENLHK/SETJEN/KUM.1/6/2017 tentang Perhutani Sosial di Kawasan Perumahan Perhutani. 
Ministerial Regulation regulates the use of land in the Perhutani working area and the net profit sharing system between cultivators and Perhutani. Some of the achievements of social forestry up to September 2017 have reached 1,053,477 ha, especially for social forestry in the Perhutani area it has not been effectively implemented, there has even been resistance from farmer organizations in conflict with Perhutani. ${ }^{34}$ Based on the study of agrarian policies after the enactment of the UUPA in 1960, there are various regulations governing agrarian affairs in Indonesia.

However, not all of these policies are oriented towards the objectives of the UUP, even in their dynamics they often cause problems in their implementation, among others ${ }^{35}$ : 1) Agrarian policies that are not in line with the principles of justice and people's welfare, instead result in gaps in land tenure 2) Lack of certainty of land rights in land control, because owners of capital prefer people. 3) Increased openness of foreign investors to control agrarian resources, which in turn leads to liberalization in Indonesia. 4) Designation of forest areas, so that many people are evicted from their land. 5) Nationalization of plantations through BUMN 6) Resolution of repressive agrarian conflicts. 7) Land tenure and land use certification that will legalize the unequal structure of community ownership and control over land, 8) Land acquisition in the process of land acquisition for infrastructure. 9) Lack of community involvement, especially farmer organizations in resolving agrarian conflicts. 10) Lack of data, information and financial support in preparing needs and realizing agrarian policies. Understanding the dynamics of cross-regime agrarian policies is also a

34 Syaikhu Usman, Regional Autonomy in Indonesia: Field Experience Emerging Challenges, $7^{\text {th }}$ PRSCO Summer Institute/4 ${ }^{\text {th }}$ IRSA International Conference.

35 Hadi Daryanto, 2014, Sekelumit Permasalahan Mendasar dalam Reforma Agraria dan Tata Kelola Hutan di Indonesia, Prosiding SemHas Reforma Agraria untuk Mendukung Tata Kelola Kehutanan, Puslitbang, Jakarta, 
matter of providing wisdom, lessons so that policymakers no longer exacerbate agrarian problems and repeat bad historical legacies in agrarian management.

One of the standard models of agrarian reform is simple land redistribution or land reform. The land object was divided into many plots and given to landless farmers. Land reform has been carried out during the 1960s to 1990s. In the early period, the objects of land redistribution were mostly non-existing agricultural land and land that was excessively above the maximum ownership limit. However, due to political changes in the new era of government since the 1970s, these land objects turned into abandoned state lands.

Since the 2000s, land reform policies have accommodated the political situation in the reform era. Landless farmers encourage the government to get land not only from abandoned state land but also from less productive land belonging to plantations. This situation is the background of the implementation of boarding land reform into agrarian reform until the last few years. According to MPR Decree No. IX of 2001, agrarian reform is also called agrarian reform ${ }^{36}$. The agrarian reform process that we discuss consists of asset reform and access reform. Asset reform means giving out parcels of state land to landless farmers or legalizing the rights to abandoned land that have long been controlled by farmers. The process of legalizing land rights in this model is accompanied by empowerment of farmers. Farmers' empowerment instruments include skills training, infrastructure development (rural roads, irrigation, electricity, etc.). These instruments help farmers access the economic system (market) so they can use their land more productively. This process is called access reform. Many

\footnotetext{
${ }^{36}$ Ketetapan MPR Nomor IX Tahun 2001
} 
experts say that the agrarian reform model which consists of asset reform is also called land reform plus. ${ }^{37}$

Agrarian reform, according to Iwan Nurdin from the National Council of the Consortium for Agrarian Reform (KPA) ${ }^{38}$, argued that the existence of agrarian reform, especially in the land sector, aims to be advanced, just and independent. The transformation of agrarian reform lies in the arrangement of agrarian resources in an effort to eliminate gaps in land tenure rights and change the pattern of agricultural life to be more productive and sustainable. In fact, agrarian reform is implemented through asset reform and access reform. Asset reform is carried out through a land redistribution program that results in land rights for farmers, allowing farmers to have control over their land. Meanwhile, access reform is related to post-activity asset reform, namely how to manage land that has been obtained by farmers, either by providing education, training and mentoring facilities and infrastructure that support productive agricultural activities integrated with economic pillars to advance farmers well-being. The transformation in the concept of agrarian reform refers to the formation of an agrarian society that is integrated into the economic pillars to improve welfare, especially with the formation of regional autonomy. For this reason, it is necessary to strive for a process of change in society which previously only tended to only carry out traditional agricultural activities towards a more orderly life order for all farmers. Efforts are needed to transform the concept of agrarian reform towards policies oriented towards asset reform and access to reform.

\footnotetext{
37 Syaikhu Usman, Regional Autonomy in Indonesia: Field Experience Emerging Challenges, $7^{\text {th }}$ PRSCO Summer Institute/4 th IRSA International Conference.

38 Waryanto, 2016, Agrarian Reform: Momentum to Realize Economic Independence of Small Communities in Supporting Food Security, Bhumi, Vol. 2 No. 2,
} 
Asset reform is urgently needed to provide certainty for community rights in cultivating land. Through the certainty of these rights, enable the recipient of assets to utilize and use them. In addition, there is a need to ensure the sustainability of benefits received by land redistribution rights recipients through the development of appropriate access reforms. In implementing agrarian reform, a comprehensive transformation of the national agrarian policy from the government and technical stages is needed so that the program can run well. This means that the agrarian reform program is not a land redistribution program, but a program that must be supported from infrastructure, investment policies to security.

Several stages that will be carried out are: 1) Availability of agrarian data a) Provision of maps of land control and use, namely holders of land rights, area and land use, land allocation; b) Determining the redistribution of abandoned, excess and absent land c) Examining soil data in the form of height/contour, suitability, soil structure, rainfall, soil moisture. 2) Establishing a special agrarian court. This is intended to immediately resolve problems if land disputes occur as a result of the program. This special court is established in every city/regency, but the most important thing is that the making of the court must be guided by Article 33 of the 1945 Constitution, namely "the land, water and the wealth contained therein are controlled by the state and used for the greatest welfare of the people"39. 3) Designation of Land for Objects of Redistribution/Land for Objects of Agrarian Reform This stage determines how much land will be distributed to farmer families/cooperatives with which they can improve their welfare. At this stage the area of land to be used for agricultural land

\footnotetext{
39 Pasal 33 UUD 1945
} 
and integrated planning includes irrigation, superior seeds, fertilizers, pesticides, animal feed, extension, banking, environmental sustainability and security have started. The agrarian reform program is not only limited to distributing land to the community, but must supported by the supporting infrastructure as above.

The agrarian reform program is implemented on the principle of "land for tenants", therefore holders of land rights are obliged to cultivate the land themselves. Rights holders are prohibited from renting, contracting, pawning, collecting, or paying other people as agricultural laborers. The land is given the right to work on, and remains their right as long as they fulfill their obligations as cultivators. This right will expire if within six months they do not cultivate the land. The land is redistributed as large as the farmer can cultivate family or cooperative. This land redistribution is prioritized for homeless farmers, small farmers, and other poor farmers who live around the land. However, what needs to be emphasized here is that the rights given to farmers on these lands are not property rights, but rights to cultivate them which can be extended continuously as long as the farmers cultivate the land. 6) Supporting Programs a) Supporting infrastructure such as land clearing, land management, infrastructure, irrigation, agricultural education, provision of agricultural equipment, superior seeds, fertilizers, pesticides, village banks; b) Production of crops and processing of agricultural or food products; c) Marketing of products guaranteed by the state through the National Logistics Agency; d) Export and import policies; e) Tightening foreign investment; The transformation in the concept of agrarian reform refers to the formation of an 'agrarian' society that is integrated into the economic pillars to improve people's welfare. For this reason, it is necessary to strive for an agrarian policy that is oriented towards 
agrarian reform towards a more prosperous life order for the greatest prosperity of the people.

Political law is identical to legal policies that are currently or have been implemented nationally by the Indonesian government, which in its implementation includes: ${ }^{40}$ (a) Legal making and legal reform of legal materials deemed foreign or not suitable for purpose law making. (b) Application of existing laws, including enforcing the functions of related institutions and training members of law enforcement. From the definition above, the political law referred to in this paper is identical to the national land law policy in favor of peasants that will be or have been implemented by the government, related to the Land Bill that is being discussed in the DPR, especially land reform as the history of national land law towards agrarian reform for the welfare and prosperity of the people. According to Rahmi ${ }^{41}$, there are five factors needed in the development of agrarian land in Indonesia, namely formal, material and ideal factors, as well as modern agrarian social factors and ideological political factors. The above opinion becomes the theoretical basis that the politics of land law in Indonesia is influenced by other legal issues, related to philosophical, juridical and sociological factors. Therefore, many experts think that the Agrarian Law is a "sensitive law", because it is related to family law, inheritance law and economic law as well as administrative law, constitutional law and even human rights. The history of Indonesian land law has noted that the state's preference for farmers was expressed through land reform policies, although it failed. The current agrarian reform policy seems to have received attention from the government. Referring to the above

\footnotetext{
40 Abdul Hakim Garuda Nusantara, 1985, Politik Hukum Nasional pada Kerja Latihan Bantuan Hukum, Surabaya,

41 Elita Rahmi, 2013, Politics of Land Law for Indonesian Farmers, The $1^{\text {st }}$ Conference of Law, Bussiness and Government,
} 
problems, in line with the philosophy of Indonesia's goals, Indonesian policy and law enforcement should aim at the welfare of the community, especially farmers, as a vulnerable group that must be protected by law in order to increase their role as affimative action, through certain policies. Without special attention to issues related to the scarcity of agricultural land for Indonesian farmers, it is difficult for Indonesian people to survive the long-term crisis due to control over agricultural products by the free market. On the other hand, globalization has become the expansion of politically defined economic activity across national and regional boundaries through increasing the movement of goods and services ${ }^{42}$, including labor, capital, technology and information through trade and services.

The agricultural land agrarian policy is an important part of the process of embodiment of agrarian reform, especially in dealing with agrarian land problems or conflicts in Indonesia. The restructuring of agrarian resources through agrarian reform policies aims to reform land agrarian resources to help people achieve justice and prosperity.

\section{CONCLUSION}

The agrarian land policy began in the reform era during the reign of President BJ Habibie, who issued Presidential Decree No. 48/1999 concerning the Policy and Regulatory Study Team in the context of Landreform Implementation. This policy applies simultaneously with the initiation of regional autonomy. The existence of agrarian reform, especially in the land sector, aims to be advanced, just and independent. Meanwhile, access reform is related to post-activity asset reform, namely how to manage land that has been obtained by farmers, either by

42 Elita Rahmi, 2013, Politics of Land Law for Indonesian Farmers, The $1^{\text {st }}$ Conference of Law, Bussiness and Government, 
providing education, training and assistance for facilities and infrastructure that support productive agricultural activities that are integrated with economic pillars to advance the welfare of local people. Several stages that will be carried out are: 1) Availability of agrarian data, 2) Establishing a special agrarian court, 3) Designation of Land for Objects of Redistribution/Land for Objects of Agrarian Reform This stage determines how much land will be distributed to farmer families/cooperatives with which they can improve their welfare, 4) The agrarian reform program is not limited to distributing land to the community, but must be supported by supporting infrastructure as above, 5) Conducting Land Redistribution After determining the land recipient, at this stage the land will be redistributed to prospective farmers or cooperatives and, 6) Supporting Programs. The transformation in the concept of agrarian reform refers to the formation of an 'agrarian' society that is integrated into the economic pillars to improve people's welfare.

\section{REFERENCES}

\section{Book}

Abdul Hakim Garuda Nusantara, 1985, Politik Hukum Nasional pada Kerja Latihan Bantuan Hukum, Surabaya,

C. Barr, Resosudarmo, LA., Mc Carthy J dan Dermawan, 2006, A. Forest and Decentralization in Indonesia, CIFOR, Bogor,

Wiradi dan Tjondronegoro, 2002, Menelusuri Pengertian Istilah Agraria,

\section{Journal}

D. Primayanti dan Ferdyansyah, 2019, Konflik Agraria Antara Gerakan Reforma Agraria Pengalengan dengan Perusahaan Daerag Agribisnisdan Pertambangan, Jurnal Kolaborasi Resolusi Konflik, Vol. I No. 1,

Elita Rahmi, 2013, Politics of Land Law for Indonesian Farmers, The $1^{\text {st }}$ Conference of Law, Bussiness and Government,

Hadi Daryanto, 2014, Sekelumit Permasalahan Mendasar dalam Reforma Agraria dan Tata Kelola Hutan di Indonesia, Prosiding SemHas Reforma Agraria untuk Mendukung Tata Kelola Kehutanan, Puslitbang, Jakarta, 
M. Sadyohutomo, 2018, The Benefits of an Agrarian Reform Model in Indonesia, IOP Conferentioon Earth and Environtmental Science 202.

Rina Rohayu. Harun, 2019. “Menyikapi Globalisasi Hukum Tanah dengan Kearifan Lokal". Media Keadilan: Jurnal Ilmu Hukum. https://doi.org/10.31764/jmk.v10i2.2250. Volume 10 nomor 2.

S. Ekawati, Kinerja Pemerintah Kabupaten dalam Desentralisasi Pengelolaan Hutan Lindung: Studi Kasus di 3 Kabupaten dalam DAS Batanghari, Jurnal Analisis Kebijakan Kehutanan, Vol. 8 No. 2,

Sediono M.P Tjondronegoro, 2003, Land Policies in Indonesia, EASRD Working Paper, Edisi 19 Juni.

Syaikhu Usman, Regional Autonomy in Indonesia: Field Experience Emerging Challenges, $7^{\text {th }}$ PRSCO Summer Institute/4th IRSA International Conference.

The SMERU Research Institute, Regional Autonomy in Indonesia, A Paper Prepared for $7^{\text {th }}$ PRSCO Summer Intitute, Bali, 20-21 Juni 2020.

Triana Rejekiningsih, 2019, Chatarina Muryani, Diana Lukitasari, Study of the History and Dynamics of the Agrarian Policy in Transforming the Indonesia Agrarian Reform, Yustisia, Vol. 8 No. 2, Edisi Mei-Agustus 2019.

Waryanto, 2016, Agrarian Reform: Momentum to Realize Economic Independence of Small Communities in Supporting Food Security, Bhumi, Vol. 2 No. 2,

\section{Laws and Regulations}

Keputusan Presiden No. 34/2003 tanggal 31 Mei 2003

Peraturan Pemerintah Republik Indonesia Nomor 11 Tahun 2010 tentang Penguasaan dan Pemanfaatan Tanah

TAP MPR Nomor IX Tahun 2001 tentang Pembaruan Agraria dan Pengelolaan Sumber Daya Alam

Undang-Undang Nomor 18 Tahun 2004 tentang Perkebunan

Undang-Undang No. 22 Tahun 1999 tentang Pemerintah Daerah

UU No. 25 Tahun 1999 tentang Perimbangan Keuangan Antara Pemerintah Pusat dan Daerah.

Undang-Undang Otonomi Daerah No. 22/1999

Undang-Undang Nomor 5 Tahun 1960 tentang Peraturan Dasar PokokPokok Agraria

Undang-Undang Pokok Agraria (No. 5/1960) yang diundangkan pada 24 September 1960

Keputusan Presiden No. 10/2001 tentang kompetensi tentang alokasi lahan 
Bintang Ulya Kharisma, Pryo Sularso, Bintara Sura Priambada, Asri Agustiwi $\mathcal{E}$ Siti Wulandari|Agrarian Land Policy on Land in Indonesia...

Peraturan Menteri Nomor P.39/MENLHK/SETJEN/KUM.1/6/2017 tentang Perhutani Sosial di Kawasan Perumahan Perhutani.

Website

Anonim, Quasi Federalism in Indonesia, Draft Forenst Trend, https://www.forest-trends.org/wp-content/uploads/imported/6-quasifederalism-in-indonesia-pdf.pdf, Diakses pada 5 Oktober 2020

BPS, 2002, Statistik Indonesia, Jakarta, www.bps.go, Diakses pada 4 Oktober 2020.

Ria Fitri, 2018, Hukum Agraria Bidang Pertanahan Setelah Otonomi Daerah, https://jurnal.hukumonline.com/a/5cb490e901fb73000e1c6bee Lhukum-agraria-bidang-pertanahan-setelah-otonomi-daerah, diakses pada 5 Oktober 2020. 